\title{
Electrochemical Study of Complexes of Tl(I) with Asparagine at DME in Non-Aqueous Medium
}

\author{
MADHU MOYAL and O.D. GUPTA* \\ Department of Chemistry, University of Rajasthan, Jaipur- 302004, India \\ gupta_od@yahoo.co.in
}

Received 30 June 2012 / Accepted 24 July 2012

\begin{abstract}
The polarographic measurements have been used to determine the overall formation constants of simple complexes of $\mathrm{Tl}(\mathrm{I})$ with asparagine. The reduction of complexes is found to be involving one electron. DeFord and Hume's treatment suggests that aspargine forms $1: 1$ and 1:2 complexes in non-aqueous medium (20\% and $40 \% \mathrm{v} / \mathrm{v}$ ethanolwater mixtures and $20 \%$ and $40 \% \mathrm{v} / \mathrm{v}$ DMF-water mixtures) at $298 \mathrm{~K}$ and $308 \mathrm{~K}$. The overall formation constants $\log \beta_{1}$ and $\log \beta_{2}$ have been calculated for $\mathrm{Tl}(\mathrm{I})$-Asparagine system. The thermodynamic functions $\Delta \mathrm{G}^{\circ}, \Delta \mathrm{H}^{\circ}$ and $\Delta \mathrm{S}^{\circ}$ have been determined for both the complexes at $298 \mathrm{~K}$ in $20 \%$ and $40 \%$ ethanol-water mixtures and $20 \%$ and $40 \%$ DMF-water mixtures.
\end{abstract}

Keywords: DC Polarogrpahy, Formation constants, Tl(I), Asparagine, DMF, Ethanol

\section{Introduction}

The use of polarographic technique for the study of complexation is well known ${ }^{1-2}$. Many workers $^{3-4}$ have studied biologically active metal complexes of amino acids which are important in analytical, biochemical and pharmaceutical fields ${ }^{5-7}$.

Thallium is used for making low melting point special glass for use in photo cells. It is used for sink-float separation of minerals. Thallium amalgum is used in thermometers for low temperature, because it freezes at $-58{ }^{\circ} \mathrm{C}$ (Pure mercury freezes at $-38{ }^{\circ} \mathrm{C}$ ).

Thallium poisoning is mainly caused by accidental up take of rat poison, which contains large amount of thallium sulphate. Thallium has negative effects upon plants such as color change of leaves and growth declines. Mammals such as rabbit are just as susceptible to the toxic effects of thallium as human. The triad of gastroentleritis polyneuropathy and alopecia is regarded as the classic syndrome of thallium poisoning.

Sharma ${ }^{8}$ has reported the electrodekinetic study of gallium(III) with $D-L$ - $\alpha$-alanine in aqueous and 25\% ethanol in water at DME. Different non-aqueous media have been taken by many workers for polarographic study of metal complexes ${ }^{9-12}$. Polarographic study of $\mathrm{Tl}(\mathrm{I})$ 
has been carried out in some binary mixed non-aqueous ${ }^{13}$ solvents with aza-18-crown-6. Gupta et al. have studied the In(III) complex with 2, 2' oxidiacetic acid in aqueous and nonaqueous medium ${ }^{14,15}$. Many workers have studied electrochemical behavior of $\mathrm{Co}(\mathrm{II})$ in acetonitrile-water mixture at $\mathrm{DME}^{16}$.

Asparagine $^{17}$ is one of the 20 most common natural amino acids. It has carboximide as the side chain's functional group. Its molecular formula is $\mathrm{C}_{4} \mathrm{H}_{8} \mathrm{~N}_{2} \mathrm{O}_{3}$. The nervous system requires asparagine. It also plays an important role in the synthesis of ammonia. The aim of the present paper is to determine the stability constants and the thermodynamic parameters of $\mathrm{Tl}(\mathrm{l})$ with amino-acid (Asparagine) in different non-aqueous medium.

\section{Experimental}

Model CL-362 polarographic analyzer was used with cell for direct-current polarogrpahic experiments. The $\mathrm{C}-\mathrm{V}$ measurements were performed with three electrode assembly, a dropping mercury electrode as working electrode, calomel as reference and platinum as counter electrode. The capillary had the following characteristics $\mathrm{m}=4.62 \mathrm{mg} / \mathrm{s}$ and $\mathrm{t}=2 \mathrm{sec}$ was used.

Analytical-grade solutions were made in double distilled water and over all study have been done in $20 \%$ and $40 \%$ ethanol-water mixtures and $20 \%$ and $40 \%$ DMFwater mixtures. Triton X-100 (0.005\%) was used to supress the polarogrpahic maxima. Nitrogen gas was passed for 10-15 minutes through each test solution to remove dissolved oxygen.

\section{Results and Discussion}

The reduction of $\mathrm{Tl}(\mathrm{I})$-Asparagine system was found to be reversible and diffusion controlled. Direct proportionality of the diffusion current to the square root of effective height of mercury column indicates the reduction to be diffusion controlled. The diffusion current $\left(i_{d}\right)$ of metal ion $\mathrm{Tl}(\mathrm{I})$ decreases with increasing concentration of the complexing agent and shift in half-wave potential suggesting complex formation. Overall formation constants were determined by DeFord and Humes method using the polarographic measurements. From the intercept of plots of $F_{j}(X)$ vs. $(X)$ the stability constants $\log \beta_{j}$ were evaluated. The results are summarized in Tables 1 and 2.

Table 1. Stability constants for Thallium-Aspargine system in $20 \%$ (v/v) ethanol-water mixture and 40\% (v/v) ethanol-water mixture

\begin{tabular}{|c|c|c|c|c|c|c|}
\hline \multirow{2}{*}{ System } & \multirow{2}{*}{ Composition } & \multirow{2}{*}{ Methods } & \multicolumn{2}{|c|}{$\begin{array}{l}\text { Stability constants } \\
20 \% \text { ethanol - water }\end{array}$} & \multicolumn{2}{|c|}{$\begin{array}{l}\text { Stability constants } \\
40 \% \text { ethanol - water }\end{array}$} \\
\hline & & & $298 \mathrm{~K}$ & $308 \mathrm{~K}$ & $298 \mathrm{~K}$ & $308 \mathrm{~K}$ \\
\hline \multirow{2}{*}{ [Tl (Asp)] } & \multirow{2}{*}{$1: 1$} & $\begin{array}{l}\text { DeFord } \\
\text { and Hume }\end{array}$ & 2.70 & 2.62 & 2.71 & 2.64 \\
\hline & & Mihailov & 2.62 & 2.39 & 2.65 & 2.21 \\
\hline $\left.\multirow{2}{*}{\mathrm{Tl} \text { (Asp) }}_{2}\right]^{-}$ & \multirow[t]{2}{*}{$1: 2$} & $\begin{array}{l}\text { DeFord } \\
\text { and Hume }\end{array}$ & 5.48 & 5.42 & 5.50 & 5.44 \\
\hline & & Mihailov & 5.52 & 5.10 & 5.43 & 5.89 \\
\hline
\end{tabular}


Table 2. Stability constants for Thallium - Aspargine system in 20\% (v/v) DMF-water mixture and 40\%(v/v) DMF-water mixture

\begin{tabular}{|c|c|c|c|c|c|c|}
\hline \multirow[t]{2}{*}{ System } & \multirow[t]{2}{*}{ Composition } & \multirow[t]{2}{*}{ Methods } & \multicolumn{2}{|c|}{$\begin{array}{l}\text { Stability constants } \\
\text { 20\% DMF - water }\end{array}$} & \multicolumn{2}{|c|}{$\begin{array}{l}\text { Stability constants } \\
40 \% \text { DMF - water }\end{array}$} \\
\hline & & & $298 \mathrm{~K}$ & $308 \mathrm{~K}$ & $298 \mathrm{~K}$ & $308 \mathrm{~K}$ \\
\hline \multirow{2}{*}{ [Tl (Asp)] } & \multirow{2}{*}{$1: 1$} & $\begin{array}{l}\text { DeFord and } \\
\text { Hume }\end{array}$ & 2.72 & 2.64 & 2.74 & 2.66 \\
\hline & & Mihailov & 2.18 & 2.15 & 2.26 & 2.10 \\
\hline \multirow[t]{2}{*}[\mathrm{Tl}(\text{Asp)})_{2}]{$^{-}$} & \multirow[t]{2}{*}{$1: 2$} & $\begin{array}{l}\text { DeFord and } \\
\text { Hume }\end{array}$ & 5.50 & 5.44 & 5.51 & 5.45 \\
\hline & & Mihailov & 5.32 & 5.72 & 5.64 & 5.92 \\
\hline
\end{tabular}

The values of stability constants decreases with temperature increase in case of $20 \% \mathrm{v} / \mathrm{v}$ ethanol and $40 \% \mathrm{v} / \mathrm{v}$ ethanol mixtures as well as in $20 \%$ and $40 \%$ DMF mixtures for Tl-Asparagine system that means stability of complex is effected by;

(i) Temperature

(ii) Due to solvation effect.

The relative value of stability constants are found for both medium in the following order. 40\% DMF-water > 20\% DMF-water > 40\% ethanol-water $>20 \%$ ethanol water mixture. The increase in stability constants values in first instance on addition of ligand shows that the complex formation is an exothermic process. However it is not always true because the stability constant is governed by other factors like viscosity, electrostatic effect etc.

Thermodynamic parameters such as enthalpy change $\left(\Delta \mathrm{H}^{\circ}\right)$, free energy $\left(\Delta \mathrm{G}^{\circ}\right)$ and entropy Charge $\left(\Delta \mathrm{S}^{\circ}\right)$ have been recorded in Tables $3,4,5$ and 6 . Negative values of $\Delta \mathrm{G}^{\circ}$ show the spontaneous nature of the process. The negative values of enthalpy $\left(\Delta \mathrm{H}^{\circ}\right)$ show that the reaction is of exothermic nature. The negative values of entropy show that formed complex is in more ordered form.

Table 3. Thermodynamic parameters for Tl-Asp system in $20 \%(\mathrm{v} / \mathrm{v})$ ethanol-water mixture at $298 \mathrm{~K}$

\begin{tabular}{ccccccc}
\hline \multirow{2}{*}{ System } & \multirow{2}{*}{ Composition } & Methods & \multicolumn{2}{c}{$\begin{array}{c}\text { Stability constant } \\
\text { 20\% DMF - water }\end{array}$} & \multicolumn{2}{c}{$\begin{array}{c}\text { Stability constant } \\
\text { 40\% DMF - water }\end{array}$} \\
\cline { 3 - 7 } & \multirow{2}{*}{$1: 1$} & $\begin{array}{c}\text { DeFord } \\
\text { and Hume }\end{array}$ & 2.72 & 2.64 & 2.74 & 2.66 \\
& & $\begin{array}{c}\text { Mihailov } \\
\text { DeFord }\end{array}$ & 2.18 & 2.15 & 2.26 & 2.10 \\
{$[\mathrm{Tl}($ Asp) $]$} & $1: 2$ & $\begin{array}{c}\left.\text { Def })_{2}\right]^{-} \\
\text {and Hume }\end{array}$ & 5.50 & 5.44 & 5.51 & 5.45 \\
& & Mihailov & 5.32 & 5.72 & 5.64 & 5.92 \\
\hline
\end{tabular}

Table 4. Thermodynamic parameters for Tl-Asp system in $40 \%$ (v/v) ethanol-water mixture at $298 \mathrm{~K}$

\begin{tabular}{|c|c|c|c|c|}
\hline System & Composition & $\begin{array}{c}\Delta \mathrm{G}^{\circ} \\
\left(\mathrm{kcal}^{2} \mathrm{~mole}^{-1}\right)\end{array}$ & $\begin{array}{c}\Delta \mathrm{H}^{\circ} \\
\left(\mathrm{kcal} \mathrm{mole}^{-1}\right)\end{array}$ & $\begin{array}{c}\Delta \mathrm{S}^{\circ} \\
\left.\text { (K.cal.deg }{ }^{-1} \text { mole }^{-1}\right)\end{array}$ \\
\hline [Tl (Asp)] & $1: 1$ & -3.682 & -2.936 & 0.005 \\
\hline$\left[\mathrm{Tl}(\text { Asp })_{2}\right]^{-}$ & $1: 2$ & -3.587 & -2.566 & 0.00359 \\
\hline
\end{tabular}


Table 5. Thermodynamic parameters for Tl-Asp system in 20\% (v/v) DMF-water mixture at $298 \mathrm{~K}$

\begin{tabular}{ccccc}
\hline System & Composition & $\begin{array}{c}\Delta \mathrm{G}^{\circ} \\
\mathrm{kcal} \mathrm{mole}^{-1}\end{array}$ & $\begin{array}{c}\Delta \mathrm{H}^{\circ} \\
\mathrm{kcal} \mathrm{mole}^{-1}\end{array}$ & $\begin{array}{c}\Delta \mathrm{S}^{\circ} \\
\text { K.cal.deg }^{-1} \mathrm{~mole}^{-1}\end{array}$ \\
\hline$[\mathrm{Tl}($ Asp) $]$ & $1: 1$ & -3.696 & -4.194 & -0.0016 \\
{$\left[\mathrm{Tl}(\text { Asp) }]_{2}\right]^{-}$} & $1: 2$ & -3.397 & -2.516 & 0.0029 \\
\hline
\end{tabular}

Table 6. Thermodynamic parameters for Tl-Asp system in $40 \%$ (v/v) DMF-water mixture at $298 \mathrm{~K}$

\begin{tabular}{ccccc}
\hline System & Composition & $\begin{array}{c}\Delta \mathrm{G}^{\circ} \\
\mathrm{kcal} \mathrm{mole}^{-1}\end{array}$ & $\begin{array}{c}\Delta \mathrm{H}^{\circ} \\
\mathrm{kcal} \mathrm{mole}^{-1}\end{array}$ & $\begin{array}{c}\Delta \mathrm{S}^{\circ} \\
\text { K.cal.deg }^{-1} \mathrm{~mole}^{-1}\end{array}$ \\
\hline$[\mathrm{Tl}$ (Asp) $]$ & $1: 1$ & -3.723 & -4.194 & 0.0015 \\
{$[\mathrm{Tl} \text { (Asp) }]^{-}$} & $1: 2$ & -7.487 & -2.516 & 0.0167 \\
\hline
\end{tabular}

\section{Acknowledgement}

The authors thank to Head, Department of Chemistry, University of Rajasthan, Jaipur for providing laboratory facilities and to CSIR for awarding JRF to one of the authors (Ms Madhu Moyal).

\section{References}

1. $\quad$ Kolthoff I M and Lingane J, J Polarography, 1952, 1, 211.

2. $\quad$ DeFord D D and Hume D N, J Am Chem Soc., 1951, 73, 5321.

3. Andreoli R, Benedeti L, Grandi G, Baltistuzzi and Gavioli G, Electrochem Acta, 1984, 9, 227.

4. $\quad$ Saxena R.S and Dhawan S K, Trans SAEST, 1983, 131(A), 18.

5. Patel R N, Panday H C and Panday K B, Bull Electrochem., 1996, 12, 612.

6. $\quad$ Khan F and Sahu P L, Ultra Scientist Phys Sci., 2000, 12, 106.

7. $\quad$ Singh B K, Jain C L and Sindhu R S, Trans SAEST, 1995, 4, 30.

8. $\quad$ Sharma V and Gupta K D, Asian J Chem., 2004, 16, 1938.

9. $\quad$ Saini K, Gupta H P and Pandey R S, J Indian Chem Soc., 2006, 83, 495-496.

10. Saini K, Gupta H P and Pandey R S, Proc Nat Acad Sci India, 2006, 76(A), II.

11. Ohmori M and Takagi M, Bull Chem Soc Jpn., 1977, 50(4), 773-778.

12. Karadia C and Gupta O D, Rasayan J Chem., 2009, 22, 403-406.

13. Monsef Z, Rounaghi G and Sarafraz A, J Inclusion Phenomena and Macrocyclic Chem., 2001, 39(3-4), 321-325.

14. Sharma S, Gupta O D and Meena, J Ultra Chem., 2008, 4(2), 165-170.

15. Sharma S, Singh M and Gupta O D, Oriental J Chem., 2008, 24(3), 1039-1042.

16. Selvaraj K, Mallika J and Selvaraj A, Oriental J Chem., 2004, 20(1), 23.

17. Nomenclature and symbolism for amino acids and peptides, Pure Appl Chem., 1984, 56(5), 595-624, DOI: 10.1351/pac198456050595 